\title{
Arun-III Project: Nepal's Electricity Crisis and its Role in Current Load Shedding and Potential Role 10 Years Hence
}

\author{
Ratna Sansar Shrestha
}

Abstract: It has become fashionable to blame 'cancellation' of the Arun-III hydroelectric project by the World Bank in 1995 in reference to Nepal's current electricity crisis, inferring that had it been implemented consumers in Nepal would not be facing the current load shedding problem. Now is the time for a dispassionate and detached analysis of the two scenarios, with and without Arun-III. The analysis of alternative scenarios demonstrates that implementation of the Arun-III 201 MW project in 1995 would not have eliminated load shedding from 2000 onwards; in fact, the power deficit may have been of a higher magnitude. Now, Arun-III planning is for a new incarnation with a capacity of $402 \mathrm{MW}$, expected to be completed within 10 years. But as the output of this project has been slated for export, it, too, will not alleviate the load shedding problem of Nepal.

Key words: Arun III Project, load sheding, Nepal

$\mathbf{N}$ epal is facing a severe electricity crisis due to supply constraint and it has been forecast that load shedding is here to stay on an increasing magnitude. During the 2008 wet season Nepal faced the problem of floods that resulted in loss of life and property in the hills and western Terai. In addition, the breach of Koshi embankment in the eastern Terai played havoc, with drowning and physical displacement, homes washed away, and farmers' investments of time, energy and resources washed away. (Some previously fertile land is now sandy beach.) Communications and infrastructure, including the road network suffered disarray. Industries also suffered due to breakdown of transportation system.

In the past, the Nepal Electricity Authority (NEA) implied that load shedding was the result of little water in the rivers. This past rainy season, however, saw an abundance of water (to the point of serious flooding), yet the NEA began imposing load shedding of two hours per day two days a weak in August 2008. The chief of the NEA's Load Dispatch Center announced in November 2008 that load shedding would be further imposed at the rate of 10 hours per day in Marga (mid-November to mid-December), 12 hours per day in Paush (mid-December to mid-January) up to a peak of 14 hours per day by the month of Magh (mid-January to mid-February). ${ }^{1}$ Many a pages have been written blaming Nepal's electricity crisis on the cancellation of the Arun-III hydroelectric project by the World Bank in 1995. It was previously scheduled for completion in 2005. Besides journalists, a number of luminaries also wrote on this topic, including a special chapter dedicated to this subject in a book by a renowned Nepali economist who has occupied the position of Finance Minister several times over last two decades and who was the first Vice Chair of National Planning Commission in 1991.2 It is time now to examine and analyze if there is any truth in it, and to draw lessons from it so that Nepal is able to learn from this episode and undertake projects for implementation in future more prudently. In other words, a dispassionate and detached analysis is called, for to test if the argument attributing current load shedding problem to the cancellation of
Arun III project by the World Bank is realistic, or not, and to find out what lessons can be learned from this episode. Such an exercise will throw light on the intellect and mindset of the Nepal 'hydrocracy' (i.e., the intelligentsia, politicos and bureaucrats involved in the water resource sector).

\section{A decade's achievement since 1995}

Let's begin by taking stock of the situation with regard to the implementation of hydropower projects in a decade since 1995, subsequent to the cancellation of Arun-III:

It can be seen from Table 1 that the Nepal Electricity Authority (NEA) succeeded in adding 165 megawatts (MW) by 2005 and an average annual generation of 982.5 gigawatt/hours (GWh) at the cost of US \$425.7 million (an average cost of $\$ 2,580$ per kilowatt) in 5.17 years. Similarly, private sector independent power producers (IPPs) added an additional 128.68 MW with an average annual generation of 810.86 GWh at the cost of $\$ 304.11$ million (an average cost of $\$ 2,363.23$ per $\mathrm{kW}$ ) in 3.63 years. Therefore, following the aborted Arun-III scheme, Nepal succeeded in increasing electrical generation capacity by $293.68 \mathrm{MW}$, with a total average annual generation of $1,793.36 \mathrm{GWh}$ at the cost of

\begin{tabular}{|l|c|c|c|c|c|c|}
\hline NEA Projects & $\begin{array}{c}\text { Capacity } \\
\text { MW }\end{array}$ & $\begin{array}{c}\text { Energy } \\
\mathbf{G W h}\end{array}$ & $\begin{array}{c}\text { Total Cost } \\
\text { Million US \$ }\end{array}$ & $\begin{array}{c}\text { Average Cost } \\
\mathbf{\$} / \mathbf{K W}\end{array}$ & $\begin{array}{c}\text { Year } \\
\text { Completed }\end{array}$ & $\begin{array}{c}\text { Construction } \\
\text { period in } \\
\text { years }\end{array}$ \\
\hline Modi & 14.8 & 92.5 & 30.0 & 2,027 & 2000 & 5 \\
\hline Puwa & 6.2 & 48.0 & 15.7 & 2,532 & 2000 & 4.5 \\
\hline Kali Gandaki-A & 144.0 & 842.0 & 380.0 & 2,639 & 2002 & 6 \\
\hline Total/Average & 165 & 982.5 & 425.7 & 2,580 & & 5.17 \\
\hline IPP Projects & & & & & & \\
\hline Khimti & 60 & 350 & 140 & 2,333 & 2000 & 4 \\
\hline Bhote Kosi & 36 & 246 & 98 & 2,722 & 2001 & 4.5 \\
\hline Indrawati & 7.5 & 49.68 & 25 & 3,333 & 2002 & 4.5 \\
\hline Syange & 0.183 & 0.962 & 0.266 & 1,454 & 2002 & 2 \\
\hline Chilime & 20 & 132 & 33.0 & 1,651 & 2003 & 5 \\
\hline Piluwa & 3 & 19.55 & 4.7 & 1,571 & 2003 & 3 \\
\hline Rairang & 0.5 & 2.32 & 1.0 & 2,000 & 2004 & 3 \\
\hline Chaku & 1.5 & 10.35 & 2.1 & 1,400 & 2005 & 3 \\
\hline Total/Average & 128.68 & 810.86 & 304.11 & 2363.23 & & 3.63 \\
\hline $\begin{array}{l}\text { Grand Total/ } \\
\text { Average }\end{array}$ & 293.68 & $1,793.36$ & 729.81 & 2,485 & & 4.05 \\
\hline
\end{tabular}

Table 1. Achievement to 2005 
$\$ 729.81$ million, completed in 4.05 years (average). This works out to an average cost of $\$ 2,485$ per $\mathrm{kW}$.

\section{Anticipated achievement under Arun-III}

Had the World Bank insisted on continuing with ArunIII, the NEA would not have been allowed to build the Kali Gandaki-A (144 MW) and Modi (14.8 MW) projects, nor would IPPs (including Chilime Hydropower Co. Ltd, a subsidiary of NEA) have been allowed to build projects with more than $10 \mathrm{MW}$ capacity due to the covenant imposed by the World Bank in the Arun-III loan document restricting Nepal from implementing projects of a capacity bigger than $10 \mathrm{MW}$. The covenant stipulated the following:

"NEA ... would seek IDA's specific consent before undertaking any investment projects that would increase generation capacity by more than $10 \mathrm{MW}$ capacity or transmission projects costing more than $\$ 3$ million. In granting such a consent, IDA would need to be satisfied that the project is economically and technically justified and part of the LCGEP, that NEA has the financial and managerial capacity to undertake the project without delaying implementation of the Arun-III or the rest of its ongoing program, that the project is consistent with HMG's public expenditure program and macroeconomic framework..."3

In this manner, if the country had started implementing Arun-III at the time, the achievement, constricted by the covenant imposed by the World Bank, during that particular decade would have been as detailed in the following table 2 .

\begin{tabular}{|c|c|c|c|c|c|c|}
\hline $\begin{array}{c}\text { NEA } \\
\text { Projects }\end{array}$ & $\begin{array}{c}\text { Capacity } \\
\text { MW }\end{array}$ & $\begin{array}{c}\text { Energy } \\
\text { GWh }\end{array}$ & $\begin{array}{c}\text { Total Cost } \\
\text { Million } \\
\text { US\$ }\end{array}$ & $\begin{array}{c}\text { Average } \\
\text { Cost \$/ } \\
\text { kW }\end{array}$ & $\begin{array}{c}\text { Year } \\
\text { Completed }\end{array}$ & $\begin{array}{l}\text { Construction } \\
\text { period in years }\end{array}$ \\
\hline Arun-III & 201 & 1715 & 1,082 & 5383 & 2005 & 10 \\
\hline Modi & - & - & - & - & - & - \\
\hline Puwa & 6.2 & 48.0 & 15.7 & 2,532 & 2000 & 4.5 \\
\hline $\begin{array}{l}\text { Kali } \\
\text { Gandaki-A }\end{array}$ & - & - & - & - & - & - \\
\hline Total/Average & 207.2 & 1763 & 1097.7 & 5297.78 & & 7.25 \\
\hline \multicolumn{7}{|l|}{ IPPs } \\
\hline Khimti & - & - & - & - & - & - \\
\hline Bhote Kosi & - & - & - & - & - & - \\
\hline Indrawati & 7.5 & 49.68 & 25 & 3,333 & 2002 & 4.5 \\
\hline Syange & 0.183 & 0.962 & 0.266 & 1,454 & 2002 & 2 \\
\hline Chilime & - & - & - & - & - & - \\
\hline Piluwa & 3 & 19.55 & 4.7 & 1,571 & 2003 & 3 \\
\hline Rairang & 0.5 & 2.32 & 1.0 & 2,000 & 2004 & 3 \\
\hline Chaku & 1.5 & 10.35 & 2.1 & 1,400 & 2005 & 3 \\
\hline Total/Average & 12.68 & 82.862 & 33.07 & 2607.1 & & 3.1 \\
\hline $\begin{array}{l}\text { Grand Total/ } \\
\text { Average }\end{array}$ & 219.88 & 1845.86 & $1,130.77$ & 5142.6 & & 5.17 \\
\hline
\end{tabular}

Table 2. Anticipated Achievement to 2005

It is now obvious that if Nepal had taken the Arun-III route, only $220 \mathrm{MW}$ capacity would have been added to the system in the decade ending in 2005, including Arun-III. This would have amounted to an average annual generation of $1,845.86 \mathrm{GWh}$ at the total cost of $\$ 1,130.77$ million, completed in 5.17 years (average). The average cost would have worked out at US\$5,143 per kilowatt.

\section{Net result}

Forced by the World Bank to abandon Arun-III, the NEA added $165 \mathrm{MW}$ at the cost of $\$ 425.7$ million, a decrease of 36 MW in the incremental capacity, at a saving of $\$ 656$ million. This indeed is a substantial saving for sacrificing $36 \mathrm{MW}$.

Although the average annual generation would have been higher by 52.5 GWh had Arun-III been implemented, by abandoning Arun-III Nepal not only succeeded in adding incremental capacity of $73.8 \mathrm{MW}$ but also succeeded in saving $\$ 400$ million in total (by the concerted efforts of NEA and the private sector). Compared to an average cost of $\$ 5,142.6$ per $\mathrm{kW}$, it actually have cost only $\$ 2,485$ per $\mathrm{kW}$ on average for the capacity added during the decade. In terms of time, Nepal also gained, as it took only 4.05 years on average to add $293.68 \mathrm{MW}$ compared to 5.17 years that would have taken to implement $219.88 \mathrm{MW}$.

\section{Load shedding scenario}

It is common knowledge that load shedding is a function of system capacity and electricity demand. For this purpose the following tables compare the two scenarios comprising the system capacity and peak demand of the respective years, (a) based on actual commissioning of various projects and (b) anticipated commissioning of Arun-III and other projects of up to $10 \mathrm{MW}$ capacity in 2005. Table 3a below depicts the actual power surplus/deficit scenario during the period based on actual commissioning of various projects during that decade (year of commissioning of respective projects based on Table 1) and peak demand of those years:

\begin{tabular}{|c|c|c|c|}
\hline Year & Peak demand4 & $\begin{array}{c}\text { Installed } \\
\text { Capacity }\end{array}$ & $\begin{array}{c}\text { Surplus/ } \\
\text { (deficit) }\end{array}$ \\
\hline 1999 & 326.4 & 313.14 & $(13.26)$ \\
\hline 2000 & 351.9 & 394.14 & 42.24 \\
\hline 2001 & 391 & 430.14 & 39.14 \\
\hline 2002 & 426 & 581.823 & 155.82 \\
\hline 2003 & 470.33 & 604.823 & 134.49 \\
\hline 2004 & 515.24 & 605.323 & 90.08 \\
\hline 2005 & 557.53 & 606.823 & 49.29 \\
\hline
\end{tabular}

Table 3a. Peak Demand and System Capacity based on actual commissioning of power projects (in MW)

It can be seen on Table 3 a that Nepal had an actual power deficit of 13.26 MW in 1999. After commissioning of various projects beginning with Khimti in 2000, the load shedding problem was buried until 2005. The problem from 2000 to 2005 was one of 'spill' (and the failure to encash such spill).

Table 3b, shows the power surplus/deficit in the alternative scenario - if Nepal had undertaken to implement Arun-III. It compares actual peak load in the respective years (as in Table 3a) and actual commissioning of various projects less than $10 \mathrm{MW}$ capacity as covenanted by the World Bank (the same as in Table 3 a except for exclusion of projects bigger than $10 \mathrm{MW}$ ) and anticipated commissioning 
of Arun-III in 2005.

Table $3 \mathrm{~b}$ makes it abundantly clear that had Nepal chosen the Arun-III route, the power deficit of $13.26 \mathrm{MW}$ in 1999 would have snowballed up to 184.72 MW in 2004 and it would only have been reduced to $24.51 \mathrm{MW}$ with the commissioning of Arun-III in 2005 (assuming that it would have been commissioned in time).

\begin{tabular}{|c|c|c|c|}
\hline Year & Peak demand6 $^{6}$ & $\begin{array}{c}\text { Installed } \\
\text { Capacity }\end{array}$ & $\begin{array}{c}\text { Surplus/ } \\
\text { (deficit) }\end{array}$ \\
\hline 1999 & 326.4 & 313.14 & $(13.26)$ \\
\hline 2000 & 351.9 & 319.34 & $(32.56)$ \\
\hline 2001 & 391 & 319.34 & $(71.66)$ \\
\hline 2002 & 426 & 327.023 & $(98.98)$ \\
\hline 2003 & 470.33 & 330.023 & $(140.31)$ \\
\hline 2004 & 515.24 & 330.523 & $(184.72)$ \\
\hline 2005 & 557.53 & 533.023 & $(24.51)$ \\
\hline
\end{tabular}

Table 3b. Peak Demand and System Capacity based on implementation of Arun-III scenario (in MW)

By choosing a scenario sans Arun-III, Nepal succeeded in avoiding an electricity crisis from 2000 to 2005 and, due to this route, the magnitude of load shedding after 2005 is also relatively lower than had Nepal chosen to implement Arun-III. In other words, until the projected completion of Arun-III in 2005, Nepal would have continued to pass through severe and ever increasing load shedding problem, begun since the late 1990s, as only about 19 MW additional capacity would have been added to the system by several projects of less than 10 MW capacity (e.g. 6.2 MW Puwa by NEA and some odd projects by IPPs totaling $12.683 \mathrm{MW}$ ).

\section{Bitter ground reality}

In order to get a correct picture of the alternative scenario, it also must be noted that there is no history of the public sector, donor funded, infrastructure projects in Nepal completing construction and implementation according to the original time schedule. The Middle Marsyangdi project commissioned in December 2008 with cost and time overruns.. NEA officialdom defensively says that this particular project is a bad example from which to draw inferences. An alternative is to draw interferences from the much acclaimed Chilime project (which succeeded to garner a number of awards and laudatory comments); it incurred a time overrun of more than five years and a cost overrun of 800 million rupees (included in the total cost at completion of 2.33 billion rupees), and it even had to change horses (i.e., the civil contractor), so to speak, in the middle of the race.

The time overruns incurred by various projects since completion of Kulekhani-I in 1982 are shown in Table 4.

Middle Marsyangdi inaugurated in December 2008 after a delay of 48 months.

With such a track record, Nepal would have been reeling under load shedding of an even higher magnitude than it

\begin{tabular}{|l|l|}
\hline Project & Time overrun \\
\hline Kulekhani I & 21 months \\
\hline Marsyangdi & 7 months \\
\hline Kali Gandaki-A & 18 months \\
\hline Chilime & 60 months \\
\hline
\end{tabular}

Table 4: Time overruns

has experienced, while awaiting completion of Arun-III, which going by the results in Table 4, would realistically not have been commissioned until 2009. More specifically, the power deficit of 24.51 MW in 2005 would have been 225.51 MW instead, and even higher in the following years until the original Arun-III project was commissioned.

\section{Potential impact on NEA, electricity users and the macro economy}

The impact of implementation of the previous incarnation of Arun-III would have been two fold: first due to the unavailability of power during the period from 2000 through 2005 as per the analysis above and, secondly, due to higher cost per installed capacity.

The primary impact of implementation of Arun-III would have been felt by the NEA in terms of lost revenue due to power deficit (Table 3b) from 2000 through 2005. Cumulative power deficit from 2000 through 2005 would have been 552.74 MW (computation based on Table 3b), which is equivalent to $1,597.86 \mathrm{GWh}$ at $33 \%$ plant factor (generally achieved by NEA on average). The monetary value of such revenue loss that NEA would have suffered amounts to 10.4 billion rupees at Rs $6.53 / \mathrm{kWh}$ (average revenue rate of NEA for 2005).7

Secondarily, and more importantly, the macro economy also would have suffered due to power shortage while ArunIII was under implementation. A study on the 'Economic Impact of Poor Power Quality on Industry-Nepal', conducted under the auspices of the USAID-SARI/Energy Program has examined the cost of electricity supply interruptions both in terms of outages as well as loss of quality of power. Momentary interruptions, unplanned and planned outages, voltage fluctuations, and supply harmonics were considered. The conclusion relevant to this article is with regard to planned outages. The industry-wide average cost of planned interruptions is calculated to be US $\$ 0.14$ per $\mathrm{kWh}^{8}$ as shown on Table 5 .

From this it is clear that due to the electricity deficit of $1,597.86 \mathrm{GWh}$ during the period under consideration, the cost to the economy of Nepal would have amounted to a whopping 15.66 billion rupees due to the planned interruptions (at the rate of US14\$, equivalent to Rs 9.80). The SARI study has used the cost of operating standby electricity generation to arrive at the cost of planned generation as the main component of it. As even the fuel cost of the standby generator exceeds Rs $15 / \mathrm{kWh}$, however, this estimate is basically cost to the industry, which is on the lower side. If one computed the cost to the economy, then the cost of the chain impact on the economy in terms of lost 
employment, the loss of purchasing power resulting in loss of demand for goods, the consequential loss of revenue by the Government of Nepal, etc., due to unavailable power, would have to be taken into consideration. Therefore, the loss to the macro economy would have been exponentially higher.

\begin{tabular}{|l|c|c|}
\hline \multirow{2}{*}{\multicolumn{1}{|c|}{ Industry }} & \multicolumn{2}{c|}{$\begin{array}{c}\text { Range with 90\% confidence } \\
\text { \$/kWh }\end{array}$} \\
\cline { 2 - 3 } & From & To \\
\hline Food, beverages, and tobacco & 0.00 & 0.15 \\
\hline Chemical, petroleum, rubber, etc. & 0.00 & 0.47 \\
\hline Textile and leather & 0.00 & 0.74 \\
\hline Iron and steel & 0.00 & 0.24 \\
\hline Hotels & 0.00 & 0.00 \\
\hline Non-metallic and minerals & 0.00 & 0.57 \\
\hline Miscellaneous & 0.00 & 0.16 \\
\hline Industry Sector Average & 0.03 & 0.25 \\
\hline
\end{tabular}

Table 5. Economic Cost of Planned Interruptions

The second set of adverse impact is related to the cost of implementation. With an estimated cost per $\mathrm{kW}$ of installed capacity of $\$ 5,143$ it would have exerted upward pressure on NEA's retail tariff. Moreover, the increase in retail tariff would also have been necessitated by the key covenants agreed by the Government of Nepal (GoN) with Asian Development Bank under Seventh Power Project, which requires the NEA to ensure $6 \%$ return on assets (later revised to "revalued assets"), $23 \%$ self investment ratio, and debt service coverage ratio of 1.2. ${ }^{9}$

Failing to revise the retail tariff upward would have forced the NEA to incur massive loss. Because the NEA is fully owned by GoN, the loss suffered by NEA is tantamount to the loss suffered by GoN and, hence the adverse impact on the macro economy as well.

Had Nepal gone with the original Arun-III, with an estimated cost per $\mathrm{kW}$ of installed capacity of $\$ 5,143$, the actual cost of implementation would have been much higher (perhaps it could have been, hopefully, capped at $\$ 8,000$ per $\mathrm{kW}$ ), as most of the donor funded projects tend not only to incur time overruns, but also cost overruns, exerting further upward pressure on NEA's retail tariff by a higher magnitude. With no tariff increase the loss to NEA would also have been higher, and the consequential adverse impact on Nepal's economy would also have been higher.

\section{The new incarnation of Arun-III}

The Government of Nepal has executed a Memorandum of Understanding (MoU) with Satluj Jal Vidyut Nigam Ltd (SJVNL) on March 12, 2008 for the implementation of Arun-III hydropower project. The salient features of this project are as follows: 10

- Type

- Installed Capacity

- Design Discharge

: Pondage run-of-river

: $402 \mathrm{MW}(6 \times 67 \mathrm{MW})$

: $320 \mathrm{~m} 3 / \mathrm{sec}$
- Gross Head

- Dam Height

- Powerhouse Type

- Annual Energy

- Project Cost

According to the MoU, the new Arun-III is being developed as an export-oriented project. Besides the capacity and energy royalty stipulated in the Hydropower Development Policy, 2001, SJVNL has also agreed to provide $21.9 \%$ power (88 MW) free of cost to GoN.

Interestingly, SJVNL estimates Arun-III to cost $\$ 859$ million (at 1995 price level) for $402 \mathrm{MW}$, which works out to $\$ 2,137$ per $\mathrm{kW}$. It is educative to note that the aborted Arun-III was going to cost $\$ 5,383$ per $\mathrm{kW}$ as its estimated cost was $\$ 1,082$ million for $201 \mathrm{MW}$. In other words, SJVNL cost estimate of $\$ 859$ million for $402 \mathrm{MW}$ is lower by $\$ 223$ million compared to its previous incarnation with just 201 MW capacity (a tragicomic situation of lower capacity project costing more than higher capacity one). This impels one to conclude that Nepal was lucky to have 201 MW capacity Arun-III project cancelled in 1995, as it has spared Nepal from another blunder in hydropower development. The new incarnation is going to be built at a reasonable cost of $\$ 2,137$ per $\mathrm{kW}$; but, unfortunately for consumers in Nepal, the cheaper electricity is slated to be exported.

The apologists for the previous incarnation of ArunIII have been doing their best to justify the high per $\mathrm{kW}$ cost of $\$ 5,383$ per kW by saying that the amount includes infrastructure development costs, like the construction of an access road and construction/ erection of transmission lines. Since 1995 there has been no construction of an access road and transmission lines of any significance in the project area and, therefore, SJVNL is going to have to build the infrastructure, thus the cost estimate must include the cost of building such infrastructure.

\section{Mitigation of Nepal's load shedding on commissioning of Arun-III}

From the content of the MoU, it is clear that this project is being developed by SJVNL as an export oriented project and, therefore, out of $402 \mathrm{MW}$ only $88 \mathrm{MW}$ will be available for utilization in Nepal. Furthermore, this project will be able to mitigate Nepal's electricity crisis to that extent only by when Nepal's demand will have risen significantly. According to the analysis conducted by the author of this article, Nepal will be facing severe load shedding even after 10 years by which time the GoN plans to add 10,00o MW to the system, including the implementation of Arun-III,11 if the GoN fails to comprehend the problem and get its act together soon. Otherwise, even after commissioning the new Arun-III, Nepal will continue to face an electricity crisis.

The electricity users in Nepal, suffering from the vagaries of load shedding, are wondering why the new incarnation of Arun-III is being developed as an export oriented project when Nepal is facing severe electricity crisis. There are certain projects on the anvil, located in the Far Western 
and Mid-Western Development Regions of Nepal (too far from the load centers) and, therefore, evacuating electricity from there to the load centers (in the Central and Eastern Development Regions) is deemed unviable mainly due to high technical loss. Technically, this is incorrect logic, as the power from these areas could easily be evacuated using a $400 \mathrm{kV}$ transmission network. But, the incremental cost of erecting high voltage transmission system might not be justified by the value of the technical loss that will be reduced, from the perspective of cost benefit analysis.

The above logic does not apply in the case of Arun-III, as it is located right at the hub of the load center, which is relatively highly industrialized and the industries in these regions are not operating at full capacity due to lack of power. The industries in the area need additional $200 \mathrm{MW}$ right now, and by the time this project will be commissioned $400 \mathrm{MW}$ will be consumed easily. Moreover, it is illogical for NEA to plan to mitigate future load shedding by importing power from India which will cost almost treble of the cost of electricity from Arun-III. It would have been logical to use cheap electricity from this project in Nepal and export only the part that Nepal will not be able to use.

\section{Lessons for future}

- Merely because the new incarnation of Arun-III (402 MW) is estimated to cost $\$ 859$ million, it cannot be said that the old incarnation (201 MW) should cost half of the new incarnation as the cost does not increase or decrease in a linear fashion. However, the cost estimate of $\$ 1,082$ million for $201 \mathrm{MW}$ is, obviously, inordinately high. It reflects very poorly on the competence and capability of those preparing the cost estimate of the previous incarnation. The Government of Nepal and the NEA should design a training program to build the capability of the technocrats involved in estimating costs as such, and impart such training to them from time to time.

- The concerned authorities, in coordination with academia, need to develop a norm as to the range of cost for hydropower implementation. For this purpose reference could be taken from other countries in the region (India, China, Sri Lanka, etc.) that have experience in developing hydropower projects.

- It is fortunate that Nepal did not implement a hydropower plant whose estimated cost per $\mathrm{kW}$ was more than $\$ 5$,ooo while the average cost of hydropower projects implemented so far in Nepal have been in the range of $\$ 2,500$ per $\mathrm{kW}$. Nepal needs to formulate a policy to choose to implement projects estimated at reasonable cost levels, especially in view of the upward pressure on retail tariff or negative pressure on NEA's bottom-line and the country's macro economy.

- Due to the World Bank covenanted restriction on undertaking any project of capacity higher than $10 \mathrm{MW}$ to implement previous incarnation of Arun-III, Nepal would have been reeling under load shedding problem from 2000 through 2005. By avoiding such load shedding Nepal succeeded in avoiding adverse impact on NEA, its consumers, GoN and the macro economy of the country. GoN should develop policies for comprehensive options assessment to prudently choose cost effective projects that can be built in time at reasonable cost.

- In view of the track record of public sector infrastructure projects, cost overruns are the norm rather than the exception. Therefore, the chances of the actual cost per kW of the previous incarnation of Arun-III increasing from over $\$ 5,000$ to around $\$ 8,000$ level was highly likely. The NEA would have been overburdened by such increased cost at commissioning and would have incurred huge losses, or it would have been impelled to pass such cost through to consumers resulting in an exorbitant retail tariff. Nepal needs to develop a mechanism to curtail cost overruns.

- In view of the track record of public sector infrastructure projects, time overruns are the norm rather than the exception. By not implementing the previous incarnation of Arun-III, Nepal unwittingly succeeded in avoiding a prolonged load shedding problem of a higher magnitude. The structure and contents of contracts and their implementation need to be improved upon, to avoid potential cost and time overruns (against the massive cost and time overruns of Middle Marsyangdi project). The capability of concerned staff to design, execute and manage construction and supply contracts needs to be improved, to preclude time and cost overruns.

- Priority should be given for the use of electricity in Nepal to help industrialize the country. This would trigger forward linkaged benefits, like employment generation, increase in purchasing power of the people, and a consequent increase in revenue for the government. Only excess and spill energy should be exported, especially when electricity generated by a project like this is highly cost effective.

\section{Conclusions}

By canceling the Arun-III project in 1995, the World Bank president at the time, James Wolfenshon, saved Nepal from the vagaries of the failed financial engineering of this project. Besides, because of this action, the magnitude of load shedding now is less severe than it would have been if implementation of the original Arun-III project had gone ahead. Load shedding in the late 1990s would have continued until now and in years to come, and current load shedding would have been of a higher magnitude. Furthermore, consumers would have been burdened with exorbitantly high tariffs, due to the high cost per $\mathrm{kW}$ of installed capacity with the implementation of Arun-III, or the NEA would have incurred losses of a higher magnitude. Moreover, the cost to the macro economy due to power deficit would also have been higher. This is one positive example of bad financial engineering that got nipped in the bud. For the average intelligentsia of Nepal, however, this is beyond comprehension, and even now they are going around moaning about the non-implementation of failed financial engineering manifest in the old incarnation of Arun-III.

Moreover, the new version of the Arun-III project, although with double installed capacity and less than half 
average cost per $\mathrm{kW}$ (and therefore requiring lower tariff), will not be substantially contributing to the mitigation of load shedding problem in Nepal, as it is being undertaken as a dedicated export oriented project. In sum, the cancellation of the earlier incarnation of Arun-III did not contribute to the load shedding and nor is the new version of Arun-III likely to solve the electricity crisis when it is commissioned.

Ratna Sansar Shrestha is a management professional specializing in financial/economic, legal and managerial aspects of the water resource sector, mainly hydropower, renewable energy technologies, environmental enterprises, and carbon trading. He is a Fellow of the Institute of Chartered Accountants of Nepal, a corporate lawyer accredited by the Nepal Bar Council, a member of Water Supply Tariff Fixation Commission and on the Board of Directors of Everest Bank Ltd and the Butwal Power Company Ltd. He was a member of the Board of Director of the NEA 2002-2004. He is currently a visiting faculty at the Kathmandu University, School of Engineering.

Corresponding address: rsansar@mos.com.np

\section{Notes}

1. Kantipur (Kathmandu Nepali language daily newspaper), November 13, 2008.

2. Ram Sharan Mahat, In Defence of Democracy: Dynamics and Fault Lines of Nepal's Political Economy (New Delhi: Adroit Publishers, 2005).

3. World Bank, 1994, Staff Appraisal Report: Arun-3 Hydroelectric Project, Washington DC: The World Bank.

4. NEA, Fiscal Year 2007/o8, A Year in Review (Kathmandu, Nepal Electrical Authority, 2008).

5. Ibid.

6. Ibid.

7. NEA, Annual Reportfor 2005 (Kathmandu, Nepal Electrical Authority, 2005).

8. http://www.sari-energy.org

9. ADB, 2001, Project Completion Report on Seventh Power Project, Manilla: Asian Development Bank.

10. http://sjvn.nic.ini/

11. Ratna Sansar Shrestha, 'The compulsion to live in the darkness even after 10,00o $M W^{\prime}$, Gorkhapatra (Nepali language daily newspaper), November 8, 2009. 